\title{
Outsiders in the Dramatic Works of John Millington Synge: In the Shadow of the Glen and the Well of the Saints
}

\author{
Sabah Atallah Khalifa Ali, Ph.D. \\ Professor \\ College of Education Ibn Rushd \\ Baghdad University \\ $\&$ \\ Zaid Ibrahim Ismael, Ph.D. \\ Instructor \\ Al-Mansour University College
}

\begin{abstract}
In times of wars, disasters, and famines, many people become victims of displacement, poverty, and social abnegation, living on the margin of the settled world. John Millington Synge's plays are abundant with such nomadic figures, who are homeless and rarely come into contact with the stagnant bourgeois society, and when they do, they exit at the end of the plays, condemning the hypocrisy and the materialism of that sedentary community. The free life of Synge's vagabonds is depicted as being superior to the restricted existence of the bourgeois world. These peripatetic characters possess a sensitive and poetic nature, acquired from their unrestricted life in the outdoors and the inspiration of the natural world. They serve the playwright in his criticism of the naivete and the materiality of the bourgeois society. This research is a character study of these nomadic people, based on British thinker's, Colin Wilson's, philosophy of the outsider. It examines these characters in two of Synge's plays, namely In the Shadow of the Glen (1903) andThe Well of the Saints (1905).
\end{abstract}

Keywords: Synge, Glen, Saints, outsider, vagabond, bourgeois, Wilson, materialism.

The outsiders, as defined by Colin Wilson (1931-2013), an English author and philosopher, in his seminal work The Outsider (1956), are characters who do not belong to the social group in which they live, being unable to conform to the social mores and the demands of that society. Their personal values, like, idealism, compassion, and aesthetic tendencies, make them superior to sedentary people. ${ }^{1}$ These characters, as Clifford P. Elendau opines, are "more sensitive than the ordinary man"and have a romantic nature similar to "the early romantics [who] had insight into the meaning present in nature."2 They are always disillusioned by the façade of order and the materialism of their community. They fail to accept the social demands and the restrictions that the settled world imposed upon them. As a result they prefer to live on the margin. This paper is a character study of the outsiders in the plays of the Irish dramatist John Millington Synge, examining two of his plays, In the Shadow of the Glen (1903) and The Well of the Saints (1905). It offers a lens through which to investigate the romantic nature of these characters, their inability to conform to the demands of the mainstream bourgeois society, and their preference for freedom in the natural world, away from the materialism and dictations of the settled world. The scope of this study does not extend to elaborate on Colin Wilson's neo-existentialist philosophy that detracts the pessimism of the early existentialist's philosophers and their belief that life is meaningless. ${ }^{3}$

Nomadic figures, like tramps, beggars, vagrants, and tinkers, are often personified in Irish drama, and they are portrayed as outsiders. ${ }^{4}$ These characters are icons of freedom in a country that strived for many centuries to obtain freedom and independence from British colonial rule. They are also reminiscences of Ireland's Gaelic past and folklore which is replete with folktales and songs, celebrating the early Celtic bards and romantic heroes. These Celtic heroes are frequently represented as wanderers, roaming and singing of the beauty of the natural world, and are symbols of freedom, living in a pre-colonial era. ${ }^{5}$ However, the political troubles, land wars, evections of poor farmers from their lands, revolutions, and famines, caused the deaths, displacement, and immigration ofa huge number of Irish citizens. Those afflicted individuals, who survived the disasters and preferred to stay home, instead of emigrating, became homeless, and joined a growing culture of tinkers and tramps, who lived a free life in the outdoors. 
Synge's plays, In the Shadow of the Glen and The Well of the Saints, feature such characters, playing major roles, who in spite of their homelessness and poverty are not anti-heroes or scoundrels in the traditional and modern sense. These characters are not highly respected by the communities in the plays; yet, they possess moral and spiritual values that put them in a superior possession to the other characters.T. R. Hen points out, in his introduction to Synge's plays, that "these people were in some sort a heroic compensation for the dusty Celtic mythology, as well as anti-types of the orthodox." Synge himself was an outsider, being a black sheep in his family. He did not conform to the Anglo-Irish Protestant ascendancy class of his family. He expressed his sympathy and identification with the native Catholic Irish people - the victims of his own class. He also objected to the inhuman acts of his brother, Edward Synge, a land-agent, who evicted poor tenants from their estates, for being unable to pay the rents-a common practice in pre-Independent Ireland. He was also unorthodox; he abandoned his family's Protestant religion, to his pious mother's grief. ${ }^{7}$

Synge's exaltation of this character type is apparent in his love letters to his beloved actress Maire O'Neil (18861952), in which he signed himself "Your Old Tramp." ${ }^{8}$ Besides, Synge also enjoyed wandering in the countryside of Wicklow, County Galway and on the Aran Islands, to the west coast of Ireland. He was acquainted with the life of Irish nomads and vagrants through direct interaction with those figures whom he met in his travels or through stories that he heard from the peasants. He documented those encounters in his essays "The Vagrants of County Wicklow" and "At a Wicklow Fair" in addition to his travel book The Aran Islands (1907).In "The Vagrants of Wicklow," Synge extols the life of tramps, saying: "In all the circumstances of this tramp life there is a certain wildness that gives it romance and a peculiar value for those who look at life in Ireland with an eye that is aware of the arts also."9

Synge's preference of these peripatetic figures represents his protest against the false values of the bourgeois society. In his comedies, In the Shadow of the Glen (1903) and The Well of the Saints (1905), these characters play major roles. They come briefly into contact with the settled world of the village, but are disillusioned by the meanness, materialism, and the rigid social strictures of that world. At the end, they return to their free lives as vagabonds with an absolute decision never to come again to such a suffocating environment. However, the audience identify with the outsider against the established world, as Vivian Mercier notes: "At the end of each of Synge's comedies ... although the solid citizen is left in command of the stage, our hearts go with the outcast."10

In the Shadow of the Glen is a one-act tragi-comedy, set in Wicklow, County Galway, Ireland. The play dramatises the story of an old man, Dan Burke, who, out of jealousy, pretends to be dead to test the fidelity of his young wife, Nora Burke, whom he suspects of having affairs with other men. While Nora is waking her ostensibly dead husband, she welcomes a visiting tramp, who seeks refuge from heavy rain outside. Nora leaves the tramp alone with the body of her husband on the pretext that she wants to inform the faraway villagers of her husband's death. While she is out, Dan terrifies the Tramp when he resurrects and reveals his plan of feigning death to trap his wife. Nora returns accompanied by a young herder, Michael Dara, and both start to arrange their forthcoming marriage, while the body of her supposedly dead husband is onstage. As she bargains for her marriage with Micahel, placing her dowry - a stocking of coins, her inheritance from her purportedly dead husband - Nora pathetically regrets her miserable life with Dan, intensified by the loneliness she experiences in her rural environment:

I do be thinking in the long nights it was a big fool I was that time, MichealDara, for what good is a bit of a farm with cows on it, and sheep on the back hills, when you do be sitting looking out from a door the like of that door, and seeing nothing but the mists rolling down the bog, and the mists again, and they rolling up the bog, and hearing nothing but the wind crying out in the bits of broken trees were left from the great storm, and the streams roaring with the rain. ${ }^{11}$

Gradually Nora realises that her new fiancé, Michael, is a materialist who is interested in her for the money and the farm she will inherit from her husband. Marriage to him will be a repetition of her unhappy marital life with Dan. When Dan resurrects and confronts Nora and Michael, Michael's true nature as an opportunist is exposed. Seeing that Nora is penniless after her expulsion from her house by her husband, he refuses to take her or to help her out of her dilemma. Nora's suffering is increased by her lonely life in the glen "with no house near [her] at all" (SG 5). She tells the Tramp that the company of her husband's dead body is better than being lonesome in this wild place: "Isn't a dead man itself more company than to be sitting alone, and hearing the winds crying, and you not knowing on what thing your mind would stay?" ( $S G 7)$. 
The play ends with the husband rising from his deathbed, terrifying his unfaithful wife and sending her and the sympathetic Tramp outside the house. Gloating over her misfortunes, her husband disdainfully reminds her:

It's lonesome roads she'll be going, and hiding herself away till the end will come, and they find her stretched like a dead sheep with the frost on her, or the big spiders, maybe, and they putting their webs on her, in the butt of a ditch. (SG 13)

The play represents Synge's critique of bourgeois values and the way women are engulfed in arranged marriages in a patriarchal community. Nora's marriage is the traditional marital transaction of an old husband arranged to entrap a young woman who does not have the will to reject, because of "her disempowered economic status." 12 Thus, out of her need to have a secure life, Nora is entrapped in such a loveless marriage to an old man, as she complains: "What way would I live and I an old woman if I didn't marry a man with a bit of a farm, and cows on it, and sheep on the back hills?" $(S G 10)$.

It is the outsider, the Tramp, who offers her a hand out of her troubles with promises of freedom, joy, and company in the natural world, away from the hypocrisy of this restrictive world. The Tramp tells Nora about his enticing adventurous free life: "I've walked a great way through the world, lady of the house, and seen great wonders" (SG5).T. R. Hennnotices that the outsider "is the eternal wanderer, who has gathered wisdom in his travels. He has both a poet's sensitivity, a sharp practical mind, and a realistic earthiness." ${ }^{13}$ Because of his poetic speech, or in Nora's own words, his "fine bit of talk," ( $S G$ 14) and his exciting free life, Nora is lured into accompanying him at the end of the play:

Come along with me now, lady of the house, and it's not my blather you'll be hearing only, but you'll be hearing the herons crying out over the black lakes, and you'll be hearing the grouse, and the owls with them, and the larks and the big thrushes when the days are warm, and it's not from the like of them you'll be hearing a talk of getting old ..., and losing the hair off you, and the light of your eyes, but it's fine songs you'll be hearing when the sun goes up, and there'll be no old fellow wheezing the like of a sick sheep close to your ear. ( $S G$ 14)

With him she will not have to suffer from loneliness in a cage-like house. His promise of protection and means of survival calms the helpless, displaced Nora: "You'll not be getting your death with myself, lady of the house, and I knowing all the ways a man can put food in his mouth" ( $S G$ 14).The tramp frees Nora from her "staid domestic world ... into the adventure of life." ${ }^{, H e}$ also assists her in gaining self-knowledge, as she realises the futility of getting married for financial security. Unlike Dan and Michael, Nora and the Tramp do not belong to this repressive settled world. At the end, she is destined to anitinerant lifestyle, but with the privilege of having the freedom she is denied by the patriarchal order. This patriarchal system is allegorical of the colonial order in Ireland. It is manifested in the traditional representation of colonisation in the British media as a marriage,where England is the dominant patriarchal authority and Ireland is the spouse in need to be controlled and managed. ${ }^{15}$ Accordingly, the play can be read as an allegory of a nation striving to free itself from the clutches of colonialism. The play ends with Nora leaving with the outsider, while Dan and his rival, Michael, sit friendly together to drink to each other's health, a typical Syngean ending:

Dan: (throwing away his stick). I was thinking to strike you, Michael Dara, but you're a quiet man, God bless you, and I don't mind you at all. (He pours out two glasses of whisky, and gives one to Michael). Your good health, Michael Dara.

Michael: God reward you, Daniel Burke, and may you have a long life and a quiet life, and good health with it. (They drink). (SG 15)

The outsiders must leave the community, seeking freedom in the natural world. Their departure at the end represents the author's protest and outcry against stereotypical social strictures. Nora's decision is not different from Henrick Ibsen's protagonist Nora Helmer in A Doll's House(1879), who likewise violates the social norm when she leaves her husband in protest against female marginalisation. Adrian Frazier states that "when Nora Burke walks out with the Tramp, it is a beautiful wish-fulfilment for the author, and a private curse on marriage, property and propriety."16

In The Well of the Saints, two blind beggars, Mary and Martin Doul, are deceived by the villagers who claim that they area handsome couple. They nourish their imagination by this false illusion, and are, thus, anxious to see themselves: "It' $d$ be a grand thing if we could see ourselves for one hour, or a minute itself, the way we'd know surely we were the finest man and the finest woman of the seven countries of the East" (WS 30). 
With the help of a wandering friar who has miraculous powers, their eyesight has been restored temporarily. Instead of seeing the ideal world they already envisioned, the beggars are humiliated by the villagers, who exploit them, through the previous lies about the couple's supposed beauty.After his recovery, Martin is led by the frenzied public outside, who are anxious to see him identify Mary. At the beginning, he believes that Molly Burne, the most beautiful woman in the village is Mary:

Oh, it was no lie they told me, Mary Doul. Oh, glory to God and the seven saints I didn't die and not see you at all. The blessing of God on the water, and the feet carried it round through the land. The blessing of God on this day, and them that brought me the saint, for it's grand hair you have ... and soft skin, and eyes that would make the saints, if they were dark awhile and seeing again, fall down out of the sky. (WS 40)

Being mocked by Molly and other girls, Martin moves from one girl to another, trying to identify Mary. The cruel villagers ridicule him and they push him from one side into another, urging him to carry on: "Try again, Martin, try again, and you'll be finding her yet" (WS 40).Finally, he is introduced to the ugly looking Mary. Gaining their eyesight, the outsiders in the play see a bleak world - the opposite of what they have imagined in their former illusionary world. They are disappointed to realise that they are an ugly aging couple. They quarrel and separate, and are obliged to toil to be able to eat and find shelter. Due to the cruelty and the maltreatment of the people, they are disillusioned and they regret regaining their eyesight. When they lose their vision again, they refuse to be cured by the saint and the villagers. They eventually leave their hypocritical society, hoping to restore the old dream world they have previously experienced. Their ultimate sightlessness revive the beautiful romantic imagination:

Mary Doul: There's the sound of one of them twittering yellow birds do be coming in the spring-time from beyond the sea, and there'll be a fine warmth now in the sun, and a sweetness in the air, the way it'll be a grand thing to be sitting here quiet and easy, smelling the things growing up, and budding from the earth.

Martin Doul: I'm smelling the furze a while back spouting on the hill, and if you'd hold your tongue you'd hear the lambs of Grianan, though it's near drowned their crying is with the full river making noises in the glen. (WS 57)

Consequently, the two vagabonds, Martin and Mary, advocate "expression and freedom over social climbing, avariciousness and close-mouthed conformity." 17 They are nostalgic to their primitive imaginary lifestyle which is an escape from the ugliness of the settled community. They are rejected by their society because their values are different. Eugene Benson states that "the only knowledge or wisdom that the beggars have learned in their journey is that mutual self-delusion is to be preferred to deception based on the lies of society." ${ }^{18}$ They gain an insight into the nature of existence. They are disillusioned by the bitter reality and the ugliness of the sighted world, which brings them misery and sadness. "It's a hard thing for a man to have his sight" (WS 45), Martin concludes, and Mary confirms, "they're bad lot those that have their sight" (Ibid.). As Mary molds her own aesthetic theory about beauty in old age, she fears that the Saint and the villagers might force them to have their eyesight again: “... what good'll our grey hairs be itself, if we have our sight, the way we'll see them falling each day, and turning dirty in the rain?" (WS 58). Martin defiantly encountersthe mob. His resistance to the Saint's attempt to cure them permanently from blindness, is a sign of his self-realisation: “... We are not asking our sight ... leave us here in our peace, at the crossing of the roads, for its best we are this way, and we're not asking to see"(WS 60). His violent reaction against the Saint and the villagers marks the end of any further interaction with society. He prefers a free life over the life of restriction: "with a sudden movement [he] strikes the can [of holy water] from Saint's hand and sends it rocketing across stage" (WS 64).

The community's cruelty is uncovered at the end as they stone the two beggars and send them away out of the stage. They head southward to a new place, escaping the villagers' "bad looks or their villainy" (WS 64), as Martin puts it. P. J. Mathews notes that The Well of the Saints "celebrates the imagination and heroism of the dissident who refuses to be coerced into conformity at the behest of the moral majority." ${ }^{19}$ Synge's portrayal of such nomadic characters continues in other plays like The Playboy of the Western World (1907) and The Tinker's Wedding (1908). These plays similarly end with the outsiders leaving the community with the ultimate decision not to come back to that stagnant material world. The outsiders are, thus, the mouthpiece of the playwright and they represent active participants in his agenda of social reform. 


\section{Notes}

1. See Colin Wilson The Outsider (London: Phoenix, 2001), 48.

2. Clifford P. Elendau, Colin Wilson, The Outsider and Beyond (California: Griffin Printing \& lithograph Company, 1979), 6-7.

3. Clifford P. Elendau defines "New Existentialism" as "the belief that human beings are free agents, that meaningful values can be found at the core of life itself, and the belief in human will as an evolutionary force with unlimited potential for development" (4).

4. See, for instance, William Butler Yeats's (1865-1939) The Pot of Broth (1905) and Padraic Colum's (18811972) The Fiddler's House (1903).

5. For more details see Jane Helleiner, Irish Travellers: Racism and the Politics of Culture (Toronto: University of Toronto Press, 2000), 42-44.

6. T. R. Henn, "Introduction," in The Plays and Poems of J. M. Synge, ed., T. R. Henn (London and New York: Bloomsbury Methuen Drama, 2001), 31.

7. For more details see Alexander G. Gonzalez, ed. Modern Irish Writers: A Bio-Critical Sourcebook (London: Greenwood Press, 1997),399.

8. J. M. Synge, Letters to Molly: John Millington Synge to Maire O'Neill, 1906-1909, ed., Ann Saddlmyer (Oxford: Oxford University Press, 1971), 80.

9. J. M. Synge, Collected Works, Vol.2, Prose, ed. Alan Price (London: Colin Smythe, 1982), 208.

10. Quoted in Eugene Benson, J. M. Synge (Macmillan: The Macmillan Press, 1982), 71.

11. John M. Synge, The Complete Works of J. M. Synge: Plays, Prose, and Poetry, ed., Aidan Arrow Smith (Hertfordshire: Wordsworth Editions Limited, 2008), 11. All subsequent references to the text are from this edition and will be parenthetically be cited within the text with page numbers. $S G$ is the abbreviation of In the Shadow of the Glen while The Well of the Saints is abbreviated as WS .

12. Rob Doggett, "In the Shadow of the Glen: Gender, Nationalism, and 'A Woman Only'," ELH, Volume 67, Number 4, (Winter 2000), 1020.

13. Henn, 31.

14. Sanford Sternlicht, A Reader's Guide to Modern Irish Drama (Syracuse, New York: Syracuse University Press, 1998), 70.

15. For more details see Jim Hansen, Terror and Irish Modernism: The Gothic Tradition from Burke to Beckett (New York: State University of New York Press, 2009), 3-4.

16. Adrian Frazier, "The Irish Renaissance, 1890-1940: Drama in English," in The Cambridge History of Irish Literature volume 2 1890-2000, eds., Margaret Kelleher and Philip O'Leary, 181-226 (Cambridge: Cambridge University Press, 2008), 194.

17. Mary Burke, "The Well of the Saints and The Tinker's Wedding," in The Cambridge Companion to J. M. Synge, ed., P. J. Mathews (New York: Cambridge University Press, 2009), 47.

18. Benson 98.

19. P. J. Matthews, "Re-thinking Synge," in The Cambridge Companion to J. M Synge, ed., P. J. Matthews (Cambridge: Cambridge University Press, 2009), 3.

\section{Bibliography}

Benson, Eugene. J. M. Synge. Macmillan: The Macmillan Press, 1982.

Burke, Mary. "The Well of the Saints and The Tinker's Wedding." In The Cambridge Companion to J. M. Synge, edited by P. J. Mathews, 41-51. New York: Cambridge University Press, 2009.

Doggett, Rob, "In the Shadow of the Glen: Gender, Nationalism, and 'A Woman Only'." ELH, Volume 67, Number 4, Winter 2000, pp.1011-1034.

Elendau, Clifford P. Colin Wilson, The Outsider and Beyond. California: Griffin Printing \& lithograph Company, 1979.

Frazier, Adrian. "The Irish Renaissance, 1890-1940: Drama in English." In The Cambridge History of Irish Literature volume 2 1890-2000, edited by Margaret Kelleher and Philip O'Leary. 181-226. Cambridge: Cambridge University Press, 2008.

Gonzalez,Alexander G. ed. Modern Irish Writers: A Bio-Critical Sourcebook. London: Greenwood Press, 1997.

Hansen, Jim. Terror and Irish Modernism: The Gothic Tradition from Burke to Beckett. New York: State University of New York Press, 2009. 
Helleiner, Jane. Irish Travellers: Racism and the Politics of Culture. Toronto: University of Toronto Press, 2000.

Matthews, P. J. "Re-thinking Synge." In The Cambridge Companion to J. M Synge, edited by P. J. Matthews. 115. Cambridge: Cambridge University Press, 2009.

Sternlicht, Sanford. A Reader's Guide to Modern Irish Drama. Syracuse, New York: Syracuse University Press, 1998.

Synge, J. M. Collected Works, Vol.2, Prose, edited by Alan Price. London: Colin Smythe, 1982.

............... J. M. Synge: The Complete Plays,edited by T. R. Henn. London and New York: Bloomsbury Methuen Drama, 2001.

.................. Letters to Molly: John Millington Synge to Maire O'Neill, 1906-1909, edited by Ann Saddlmyer. Oxford: Oxford University Press, 1971.

........, John M. The Complete Works of J. M. Synge: Plays, Prose, and Poetry, edited by Aidan Arrow Smith. Hertfordshire: Wordsworth Editions Limited, 2008.

Wilson, Colin. The Outsider. London: Phoenix, 2001. 